\title{
The Values of Local Wisdom in East Belitung: Maras Taun as a Learning Source of Biodiversity and Character Development for High School Students
}

\author{
Christine Juliana $^{1 *}$, Suhartini ${ }^{2}$, Haniah ${ }^{3}$, Peranciscus Aryanto ${ }^{3}$, and Andi \\ Susanto $^{4}$ \\ ${ }^{1}$ Master of Biology Education, Faculty of Mathematics and Natural Sciences, Universitas Negeri Yogyakarta, \\ Indonesia \\ ${ }^{2}$ Department of Biology Education, Faculty of Mathematics and Natural Sciences, Universitas Negeri Yogyakarta, \\ Indonesia \\ ${ }^{3}$ Culture and Tourism Office of East Belitung \\ ${ }^{4}$ Lembaga Adat Melayu of East Belitung \\ ${ }^{*}$ Corresponding author. Email: tine.juliana@gmail.com
}

\begin{abstract}
East Belitung Regency has one of the local wisdom which is a tradition that is still being carried out for a longago called Maras Taun. This local wisdom is important to introduce to students as part of the learning process because it is close to daily life. This study aimed to know the values of local wisdom Maras Taun in East Belitung as a source of learning material on biodiversity and character development for high school students. Data were collected through field observations and interviews. The data obtained were analyzed descriptively using the analysis model, those are data collection, reduction, data presentation, and conclusion drawing. Primary data in this study was the value of local wisdom Maras Taun as a local wisdom in East Belitung to develop the character of students and analyze the biodiversity used in the event and its conservation efforts. The results showed that there were 12 values of character development from Maras Taun, those are religiousness, honesty, tolerance, discipline, hard-working, independence, democracy, curiosity, love homeland, communication, environment care, and responsibility. The results of the analysis of biodiversity used in Maras taun event can be used to assess the level of genetic diversity and species, along with challenges/threats and conservation efforts.
\end{abstract}

Keywords: Local wisdom, Maras taun, Biodiversity, Character development

\section{INTRODUCTION}

Biodiversity includes all life at the level of genes, plant species, animals, microorganisms, ecosystems, and ecological processes [1]. Currently, biodiversity is threatened with extinction due to land conversion for crop and animal agriculture, fishing industry [2], and climate change [3]. Therefore, all parties must conserve biodiversity from the threat of extinction. Affording the conservation, there must be accompanied by the maintenance of traditional knowledge systems [4], among others, through local wisdom. Besides, conservation can be carried out by managing Indonesia's biological wealth in a sustainable manner which includes terrestrial and marine ecosystems, agroecosystem and production areas, and conservation.

Local wisdom can be utilized as a learning resource and a base knowledge to innovate the biology learning process. Students can observe the environment or use their knowledge to solve the problems in daily life that come from local wisdom, conservation, natural resource preservation through education [5]. This makes the biology learning process more meaningful so that the aim of learning or competencies can be achieved well [6].

Besides from learning materials, character development is very important to be developed to shape the character of the nation. Character 
development can be done through the implementation of local wisdom that exists in the region because it is a part of knowledge, a way of life, and a life strategy in the form of activities carried out by local communities in fulfilling their needs [7]. Also, the value of local wisdom can be a great force in building the national character [8]. Cultural values and national character in Indonesia are rooted in religion, Pancasila, culture, and the goals of national education. In the world of education, local wisdom can be linked with learning. According to [9] in [10] there are 18 cultural values and national characters as follows: religious; honest; tolerance; discipline; hard work; creative; independent; democratic; curiosity; nationalism; love the motherland; rewarding achievements; communicative, friendly or proactive; love peace; like to read; social care; responsible.

One of the local wisdom in East Belitung is Maras Taun, which is thought to have local wisdom values that are in accordance with the culture and character of the nation such as religiousness, honesty, tolerance, discipline, hard-working, independence, democracy, curiosity, love homeland, communication, environment care, and responsibility. The researcher wants to integrate this local wisdom with Biology because the tradition has character values and a lot of biodiversity, so that it can be used to study biodiversity at the level of genes and species along with efforts to conserve biodiversity. This culture has been passed down from generation to generation that is formed by interactions with the environment and communities. Once, people used various plants, animals, and environments to celebrate ceremonies or traditions. One example of things that are passed on to the next generation is the use of firewood that is not arbitrary because there are several types of wood when it burned then the smoke can cause poisoning. In order to conserve biodiversity, people will replant plants in the old kubok. According to [11] in [12], local wisdom is a policy that rests on a traditionally institutionalized philosophy, values, ethics, and behavior to manage resources (natural, human, and cultural) sustainably.

The author wants to know whether there is a coherence between the ceremonies in the implementation of Maras Taun, character values, and biodiversity which are used as learning resources and character development for high school students. Therefore, this paper aims to know the character values contained in the local wisdom of East Belitung Maras Taun for the character development of high school students and to analyze Maras Taun as a source in learning biodiversity and its conservation efforts.

\section{RESEARCH METHOD}

This research uses a descriptive method. The subjects in this study were ten people in the province of East Belitung including the community, the head of the East Belitung Malay Traditional Institute (LAM), teachers, and staff of the East Belitung Culture and Tourism Office, using purposive sampling. The objects of local wisdom analyzed are the character values contained in the tradition of the celebration as well as the various types of biodiversity utilized in Maras Taun along with efforts to conserve biodiversity in East Belitung. Data were collected through field observations and interviews. The data obtained were analyzed descriptively using the analysis model according to [13], those are data collection, reduction, data presentation, and conclusion drawing.

\section{RESULTS AND DISCUSSION}

The data of this research were obtained from the results of interviews with the people of East Belitung who had been related to Maras Taun celebration through observation and research documentation. The primary data in this study is the understanding of the East Belitung people about the character values developed, the various types of biodiversity used in Maras Taun celebration, and its conservation efforts. Maras taun is a harvest thanksgiving ceremony which is held once a year because most of the people make a living as farmers.

According to Curriculum 2013, there are three core competencies, such as the core competencies of attitudes, knowledge, and skills. Core Competencies are designed in four interrelated groups, that is linked to spiritual attitudes (KI-1), social attitudes (KI-2), knowledge (KI-3), and skills (KI-4). The four groups become a reference for basic competencies and must be developed in an integrative learning event. Competence concerning religious attitudes and social attitudes is developed indirectly, namely when students learn about knowledge (KI-3) and skills (KI4). Attitude core competencies in the 2013 curriculum are divided into two, namely spiritual attitudes (KI-1) and social attitudes (KI-2) [14]. Spiritual attitudes are related to the formation of students who are faithful and pious, while social attitudes are related to the formation of students who have noble, independent, democratic, and responsible morals [15]. Spiritual attitudes can provide understanding to distinguish something right or wrong based on faith and piety to God. Meanwhile, social attitudes concern community life as a form of student interaction with nature, the school environment, and the surrounding environment [16]. 


\subsection{Correlation Between Maras Taun and Biodiversity}

The implementation of Maras Taun has been around for a long time. This tradition is carried out by every village that has kedukunan. In this case, a shaman acts as the head of the village/head of the kubok as well as the head of the tradition who heads the village area. Kubok is a small village consisting of several families [17] in [18] and there is a village boundary marked with a "dinding kampung / hutan watas" or limited by water flow. Those are forms of the boundaries of the village so that the area of one village can be known.

Maras Taun is one of the traditions that is celebrated every year after harvest which is carried out by the people of Belitung. It used to be called Selamatan Kampung which was led by a village shaman together with the community [19]. Maras Taun means the end of the year or cuts the year. In general, this means limiting the old year and taking the new year by being grateful for the harvest so that next year the community will get better results. Harvest products in the form of farm/garden products, livestock, and fishing products. Maras Taun is usually held in January or Muharram month such as in Simpang Pesak, Dukong, Kelumpang, Batu Itam, and Suge Villages for Dusun Bira in April, while for other villages or hamlets depending on the agreement.

The Maras Taun tradition aims to maintain the friendship, an expression of gratitude for the harvest, and chopping the population (census) in one kubok (village). This can be seen from the lepat amount that is given by the head of the household in 1 house to the head of the kubok. For those who are just born, it will be seen from the head of the family carrying a white bowl, candles, free-range chicken eggs, money "pekeras" (money as willing). Meanwhile, for people who move from or to other kubok, it can be seen from the incense and other conditions given to the village shaman. Later this will be written by a shaman and recorded.

The village shaman (dukun kampung) is one of the highest traditional holders and does not stand alone. There are representatives of shamans such as young shamans (dukun muda), wind shaman (dukun angin), water shaman (dukun aik), coastal shaman (dukun laut/dukun pesisir pantai), lebai (prayer reciter), nuje (mosque keeper), pengguling (midwife). The appointment as the village shaman is based on lineage or it is selected in deliberations if the descendants of the village shaman are not willing to be choosen. This shaman plays a role in treating people who are medically and non-medically ill, as well as guardians of the village area from interference by supernatural beings. Regarding Maras Taun, the role of a village shaman is needed when opening a field (ume). Ume is one of the artificial ecosystems formed by the people in Belitung to produce food, especially rice. The shaman will tell you the procedures because they are also believed to preserve the forest which is believed to be the dwelling place for spirits [20].

Maras Taun celebration can be held for 3-7 days. The preparation for the event is started with the activities arranged as the following:

\section{a. Establishing Committee}

The society organizes committee deliberately and democratically. The committee established consists of a steering committee, organizing committee, and some divisions as needed such as the consumption division and others.

b. The use of wood for cooking and making Maras Taun's stage

In Maras Taun's preparation, the society cooperates in the cooking process, making stage and, etc. Not all types of trees in the forest can be used as wood for cooking or stage building. Normally, the woods used for making stage are Pelempang Putih (Adinandra sarosanthera Miq.), Pelempang Hitam (Adinandra domosa Jack), Medang (Alseodaphne bancana Miq.), and Betor (Calophyllum sp.). For the cooking process, the wood used will be chosen selectively. Parak (Amoora sp.), Pelangas (Aporosa aurita Baill) and Melangan (Dysoxylum sp.) are the kinds of wood that produce smoke when they burn. It is poisonous if someone inhaled it. Usually, society uses Jemang (Rhodamnia cinerea), Samak (Syzygium lepidocarpa Kurz.), and Pelawan Kiring (Tristaniopsis whiteaana) as firewood. The society knows the types of woods that are safe to use can be an important local knowledge (Ethnobotany) and being society's socioecological pattern of life. The values reflected from local wisdom implementation can be used to preserve and protect plants passed down to the next generation. The availability of these woods depends on society agreement in calculating how much wood they have to take per unit of time (day, week, month, year). It aims to use the wood sustainably, conformity with the carrying capacity of the forest ecosystem in their village until they return to cutting logs in the same place at a later date [21]. Carrying capacity is a place's ability to support living things optimally for a long period [22].

\section{c. Contribution}

All the society in one Kubok will participate in making contributions based on the deliberations and 
the capacity of each family. The contribution can be obtained from the biodiversity of plants or animals like rice (Oryza sativa), lepat, emping beras, ayam kampung (Gallus gallus domesticus), deer (Muntiacus muntjak), pelanduk (Tragulus javanicus), coconut (Cocos nucifera), fish caught from the sea by the capabilities of each family. All of these things reflect the attitude of helping each other and build togetherness among the people in Kubok.

d. Selamatan (the activity for showing gratitude to God)

This event is held the day before the main event. People make a pilgrimage in the morning and then selamatan will be held before/ after zuhr or before Azar. It is attended by religious leaders, agency officials, (pemuka adat) tradition leaders, and society. This event will be opened by the village shaman (dukun kampong), followed by reciting the prayer for the safety and well being of the entire society. Then, it is ended with having a meal together.

\section{e. Celebration of Maras taun}

The main event of Maras Taun consists of an opening, remarks from the headman of the village, then prayers and the last is rituals. Before and after the event, the people were treated to various performances of East Belitung traditional arts, such as betiong, lesong panjang, besepen, beripat beregong, begasing, begubang, becampak, dulmuluk, and begambus. When Maras Taun is held the village shaman (kik dukun) will give advice/prohibitions to the youth villagers about experiences of the past year, the information of new land clearing for the village (kubok) and how long the celebration will take. For 24 hours there should be no activities such as slashing, burning and picking plants. For kubok who are still opening new fields/shifting fields, various types of rice plants are planted such as makrembudingan rice, makkelak rice, lintang berayun rice, ampai rice; glutinous rice types such as pulut mas / white sticky rice, and pulut sisilan / black sticky rice (Oryza sativa var. glutinosa); cassava (Manihot esculenta), kembilik / black potato (Plectranthus rotundifolius), cucumber (Cucumis sativus), pumpkin (Cucurbita sp.), galingale (Kaempferia galanga), planted chilies (Capsicum frutescens). The existence of shifting fields means that one kubok has moved to a new location. The old land that will be occupied is still planted with various types of plants such as jackfruit (Artocarpus heterophyllus), cempedak (Artocarpus integer Merr.), durian (Durio zibethinus), rambutan (Nephelium lappaceum L.), nyato (Palaquim sp.) around the house liveable. This is done to prevent extinction and preserve plants. If the location of a new kubok is left it is called bebak. If kubok has been inhabited for a long time and grows trees, it is called kelekak. The wooden houses that can still be used by the kubok community are taken to a new location to make a new house. Among them are meranti (Shorea sp.), and Bulin (Eusideroxylon zwageri T. et B). Usually moving the kubok is not far from the previous kubok location, depending on the area of their ume (field). The area of land used depends on the information of the village shaman after carrying out the land clearing ritual. Because in one kubok there are usually 10-15 houses and their fields. One house has 1 jurai of land. The people of Belitung have a measure called jurai. 1 jurai $=45-50$ depa . 1 depa $=1.8$ meters. So you can imagine how much land is for one house.

When opening a new land or nebas (cutting a tree), the shaman will inform the time and place for nebas. It started with the shaman will pray and give a sign by sowing kesalan in the form of unsalted flour consisting of a mixture of neruse/gandarusa leaf slices (Justicia gendarussa), ati-ati leaf/iler plant (Coleus sp.) and rice flour. Then, parang (machete) is thrown into one of the largest trees so that it sticks into the tree. This indicates that the society can start cutting the tree and is marked with a stake. However, if parang (machete) is thrown does not stick into the tree, the opening new land in that location is stopped. Based on society belief, the supernatural being in the forest does not allow opening new land in that location. This certainly helps to conserve the habit of existing trees. The following table shows the results of plant identification showing the existence of genetic and species-level biodiversity

Table 1. The results of plant species identification based on the level of biodiversity

\begin{tabular}{|l|l|}
\hline Biodiversity of gen level & Biodiversity of species level \\
\hline Rice (Oryza sativa) with varieties: & $\begin{array}{r}\text { Jackfruit (Artocarpus heterophyllus) and cempedak fruit (Artocarpus } \\
\text { integer Merr.) belong to Genus Artocarpus; }\end{array}$ \\
\hline
\end{tabular}




\begin{tabular}{|c|c|}
\hline Biodiversity of gen level & Biodiversity of species level \\
\hline \multirow{6}{*}{$\begin{array}{l}\text { pulut mas (white glutinuous rice) } \\
\text { and pulut sisilan (black glutinuous } \\
\text { rice), makrembud ingan rice, } \\
\text { makkelelak rice, lintang berayun } \\
\text { rice, ampairice. }\end{array}$} & $\begin{array}{l}\text { - Pelempang putih (Adinandra sarosanthera Miq.) and pelempang hitam } \\
\text { (Adinandra domosa Jack) belong to Genus Adinandra; }\end{array}$ \\
\hline & $\begin{array}{l}\text { - Bulin (Eusideroxylon zwageri T. et B) and Medang (Alseodaphne } \\
\text { bancana Miq) belong to famili Lauraceae; }\end{array}$ \\
\hline & $\begin{array}{l}\text { - Jemang (Rhodamnia cinerea), samak (Syzygium lepidocarpa Kurz.), } \\
\text { and pelawan kiring (Tristaniopsis Whiteaana) belong to famili } \\
\text { Myrtaceae; }\end{array}$ \\
\hline & $\begin{array}{l}\text { - Cucumber (Cucumis sativus), pumpkin (Cucurbita sp.) belong to famili } \\
\text { Cucurbitaceae; }\end{array}$ \\
\hline & $\begin{array}{l}\text { - Kembilik/black potato (Plectranthus rotundifolius) and ati-ati leaf/iler } \\
\text { plant (Coleus sp.) belong to famili Lamiaceae; }\end{array}$ \\
\hline & $\begin{array}{l}\text { - Betor (Calophyllum sp.), neruse leaf/gandarusa (Justicia gendarussa), } \\
\text { cassava (Manihot esculenta), galangal (Kaempferia galanga), chili } \\
\text { (Capsicum frutescens), durian (Durio zibethinus), rambutan } \\
\text { (Nephelium lappaceum L.), nyato (Palaquim sp.), and meranti (Shorea } \\
\text { sp.). }\end{array}$ \\
\hline
\end{tabular}

According to the table above it can be seen the genetic level of biodiversity shows that variaty or differences in genes occurred within one species of living things. Meanwhile, species-level biodiversity shows the diversity or variation found in various or different types/ species of living things.

In Maras Taun, there is a tradition called Makan Bedulang. It is a procession done by eating together in one pan which is surrounded by four people in a family environment or a traditional ceremony. The variety of food served adjusts the purpose of makan Bedulang [21]. This tradition consists of ethnoscience which is integrated with socio-ecology. It can be seen in the use of foodstuffs which is available from nature, crafting dulang, tudong, mats, and the use of wood in cooking activities. By preserving the tradition of Makan Bedulang, it can maintain the link of the social system of the East Belitung people, teach the concept concerning human relationships with the surrounding natural environment, and preserve plants and animals.

\subsection{The Correlation Between Maras Taun toward Biodiversity and Character Development}

Maras taun has a good character value in maintaining traditions and preserving biodiversity. The following table shows the relationship between Maras Taun toward biodiversity and character development. 


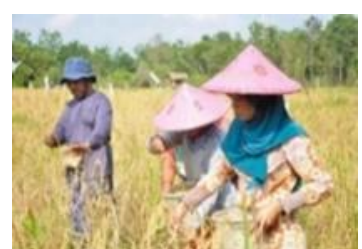

Figure 1. Harvesting

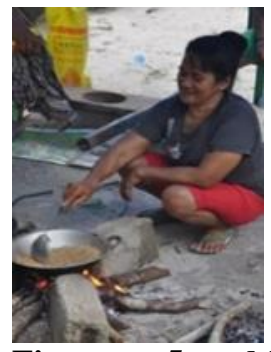

Figure 5. Making Figure 6. Pounding rice emping beras

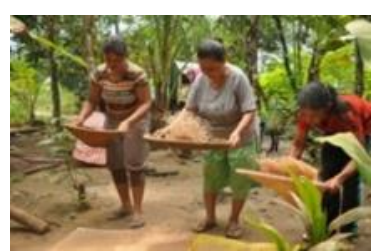

Figure 2. Filtering rice

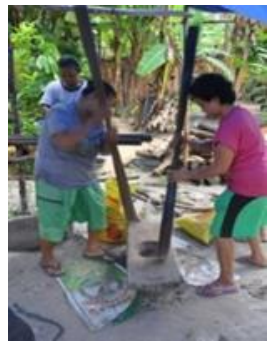

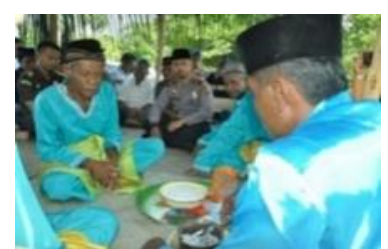

Figure 3.The shamans gathering

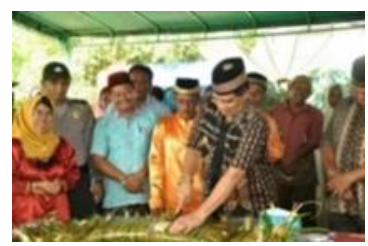

Figure 7. Cutting lepat Figure gede

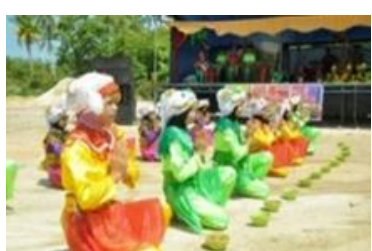

Figure 4. Traditional dance

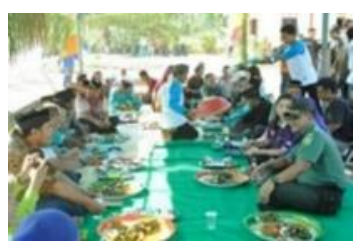

8. Makan bedulang

Table 2. The Correlation Between Maras Taun Toward Biodiversity and Character Development

\begin{tabular}{|c|c|c|}
\hline No & $\begin{array}{l}\text { The activity included in } \\
\text { Maras Taun }\end{array}$ & Explanation \\
\hline 1. & Establishing Committee & $\begin{array}{l}\text { All necessities needed for Maras Taun and entire things related to the } \\
\text { committee of the event are discussed by society. } \\
\text { The values of local wisdom/ character values: Democracy }\end{array}$ \\
\hline 2. & $\begin{array}{l}\text { The use of wood for cooking } \\
\text { and making Maras Taun's } \\
\text { stage }\end{array}$ & $\begin{array}{l}\text { There is honest and correct information about selecting the wood for the } \\
\text { cooking activity and making stage. It passes on to the next generation. } \\
\text { The values of local wisdom/ character values: Honesty } \\
\text { The implementation of biodiversity conservation: People use wood } \\
\text { necessarily and replant the tree after removing it. } \\
\text { Plants or animals used for Maras Taun: Pelempang putih (Adinandra } \\
\text { sarosanthera Miq.), pelempang hitam (Adinandra domosa Jack), medang } \\
\text { (Alseodaphne bancana Miq), betor (Calophyllum sp.), jemang (Rhodamnia } \\
\text { cinerea), samak (Syzygium lepidocarpa Kurz.), dan pelawan (Tristaniopsis } \\
\text { whiteaana). }\end{array}$ \\
\hline 3. & Contribution & $\begin{array}{l}\text { There is good communication between the village headman and villager } \\
\text { about how big Maras Taun will be. } \\
\text { The values of local wisdom/ character values: Communication } \\
\text { The implementation of biodiversity conservation: Plants or animal donated } \\
\text { for Maras Taun is livestock or farm produce, as an implementation of } \\
\text { biodiversity conservation.. } \\
\text { Plants or animals used for Maras Taun: Rice (Oryza sativa), ayam kampung } \\
\text { (Gallus gallus domesticus), deer (Muntiacus muntjak), pelanduk (Tragulus } \\
\text { javanicus), coconut (Cocos nucifera). }\end{array}$ \\
\hline
\end{tabular}




\begin{tabular}{|c|c|c|}
\hline No & $\begin{array}{l}\text { The activity included in } \\
\text { Maras Taun }\end{array}$ & Explanation \\
\hline 4. & $\begin{array}{l}\text { Selamatan (The activity for } \\
\text { showing gratitude to God) }\end{array}$ & $\begin{array}{l}\text { Society prays for their safety and well being. } \\
\text { The values of local wisdom/ character values: Religiousness }\end{array}$ \\
\hline 5. & Celebration of Maras Taun & 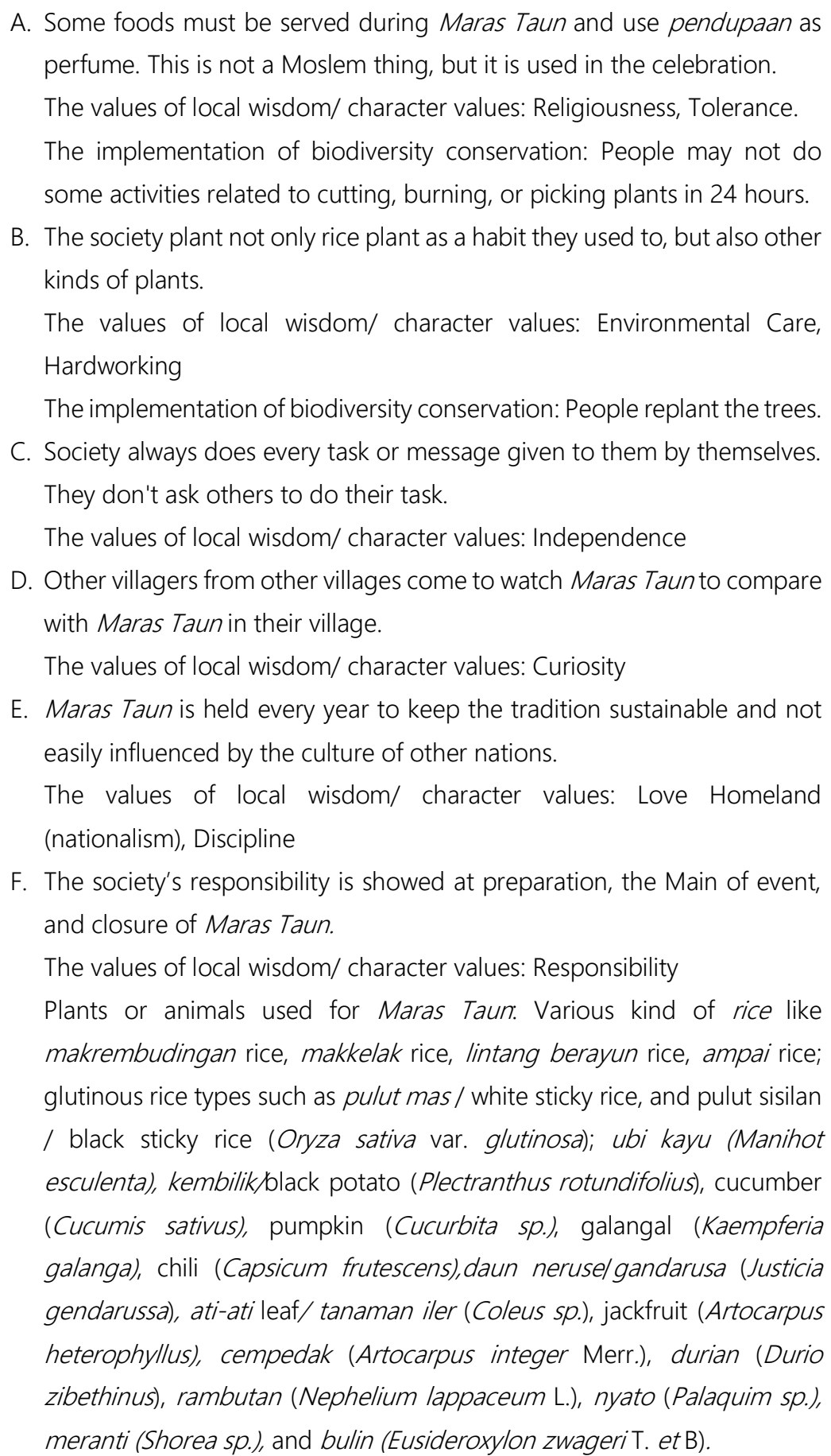 \\
\hline
\end{tabular}


Based on the table above, it shows that Maras Taun teaches biodiversity that is used for the event, therefore it needs to be preserved. Teachers can integrate biodiversity material with basic competencies (KD) 3.2 Analyze data from observations of various levels of biodiversity (genes, species and ecosystems) in Indonesia along with threats and their sustainability and KD 4.2 presentation of observations of various levels of biodiversity (genes, species and ecosystem) in Indonesia and the proposed efforts to conserve Indonesia's biodiversity based on the results of analysis of threat data to the preservation of biodiversity and typical Indonesian plants in various forms of information media with the local wisdom. This makes it easier for students to construct modern scientific concepts and still maintain the local wisdom of each ethnic group [23]. Besides, Maras Taun also teaches several values to develop the character of high school students such as religiousness, honesty, tolerance, discipline, hard-working, independence, democracy, curiosity, love homeland, communication, environment care, and responsibility. The value of local wisdom can be included by the teacher in the lesson plan (RPP).

\section{CONCLUSION}

Teachers can integrate the values of Maras Taun into the material of genetic and species level biodiversity and its conservation efforts are based on the table of the relationship between Maras Taun and biodiversity and character development, therefore students can easily construct lesson concepts and maintain existing local wisdom. There were 12 values of character development from Maras Taun, those are religiousness, honesty, tolerance, discipline, hardworking, independence, democracy, curiosity, love homeland, communication, environment care, and responsibility. As expected, students can develop characters in analyzing biodiversity at the level of genes and types along with efforts to conserve biodiversity.

\section{ACKNOWLEDGMENTS}

The author would like to thank all respondents, Culture and Tourism Office of East Belitung, and Lembaga Adat Melayu of East Belitung.

\section{REFERENCES}

[1] V. K. Singh, Biodiversity Conservation, Biochemical and Cellular Archives, 2016. DOI: https://doi.org/10.3126/banko.v19i1.2175
[2] E. Crist, C. Mora, R. Engelman, The interaction of human population, food production, and biodiversity protection, Science 356 (2017) 260264.

DOI: https://doi.org/10.1126/science.aal2011

[3] C. Bellard, C. Bertelsmeier, P. Leadley, W. Thuiller, F. Courchamp, Impacts of climate change on the future of biodiversity, Ecology Letters 15 (2012) 365-377. DOI: https://doi.org/10.1111/j.14610248.2011.01736x

[4] S. Sunarmi, Melestarikan Keanekaragaman Hayati Melalui Pembelajaran Di Luar Kelas Dan Tugas Yang Menantang, Jurnal Pendidikan Biologi Universitas Negeri Malang 6 (2014) 117974.

[5] S. Alimah, Kearifan Lokal Dalam Inovasi Pembelajaran Biologi: Strategi Membangun Anak Indonesia Yang Literate Dan Berkarakter Untuk Konservasi Alam, Jurnal Pendidikan Hayati 5 (2019) 2-3. DOI: https://doi.org/10.33654/jph.v5i1.574

[6] Y. Pantiwati, Pemanfaatan Lingkungan Sekolah sebagai Sumber Belajar dalam Lesson Study untuk Meningkatkan Metakognitif, Jurnal Bioedukatika 3 (2015) 28. DOI: https://doi.org/10.26555/bioedukatika.v3i1.4144

[7] R. Njatrijani, Kearifan Lokal Dalam Perspektif Budaya Kota Semarang, Gema Keadilan 5 (2018) 16-31. DOI: https://doi.org/10.14710/gk.5.1.16$\underline{31}$

[8] Y. Harmawati, A. Abdulkarim, R. -, Nilai Budaya Tradisi Dieng Culture Festival sebagai Kearifan Lokal untuk Membangun Karakter Bangsa, Journal of Urban Society's Arts 3 (2016) 82-95. DOI: https://doi.org/10.24821/jousa.v3i2.1477

[9] E. Irawan, Implementasi Penanaman Karakter Melalui Matematika Pada Kurikulum 2013, Ibriez : Jurnal Kependidikan Dasar Islam Berbasis Sains 1 (2016) 4-5. DOI: https://doi.org/10.21154/ibriez.v1i1.4

[10] Team, D, Development of Cultural Education and National Character. Jakarta: Curriculum Center of the Ministry of National Education's Research and Development Center, 2010.

[11] Daniah, Pelestarian Biodiversitas melalui Penguatan Kompetensi Budaya Guru Berbasis Kearifan Lokal (Local Wisdom), Prosiding Seminar Nasional Biotik 2018, 2018. 
[12] M. Abubakar, Building the Spirit of Nationalism with the Frame of Local Wisdom of the Acehnese People Overview of Resilience Building the Spirit of Nationalism with the Frame of Local Wisdom of the Acehnese People Overview of Food Security, Ministry of State Secretariat Republic of Indonesia, 2010, Accessed on: Dec. 2015, [Online]. Available: www.setneg.go.id

[13] M. B. Miles, A. M. Huberman, J. Saldana, Qualitative Data Analysis: A Methods Sourcebook Third, Arizona State University, 2014.

[14] H. Hasanah, I. G. Nurjaya, M. Astika, Pengintegrasian Sikap Spiritual dan Sikap Sosial dalam Pembelajaran Teks Ulasan Film/Drama di Kelas XI MIPA SMA Negeri 3 Singaraja, EJurnal Jurusan Pendidikan Bahasa dan Sastra Indonesia Undiksa 7 (2017) 3.

[15] Darmansyah, Teknik Penilaian Sikap Spritual dan Sosial dalam Pendidikan Karakter di Sekolah Dasar 08 Surau Gadang Nanggalo, Al-Ta lim Journal $21 \quad$ (2014) 14 . DOI: https://doi.org/10.15548/jt.v21i1.67

[16] E. Gusviani, Analisis Kemunculan Sikap Spiritual Dan Sikap Sosial Dalam Kegiatan Pembelajaran IPA Kelas IV SD Yang Menggunakan KTSP Dan Kurikulum 2013, EduHumaniora Jurnal Pendidikan Dasar Kampus Cibiru 8 (2016) 97-98. DOI: https://doi.org/10.17509/eh.v8i1.5127

[17] A. D. Wildan, M. Dulkiah, Irwandi, Pemaknaan dan Nilai dalam Upacara Adat Maras Taun di Kabupaten Belitung, Panggung, E-Jurnal ISBI Bandung 29 (2019). DOI: https://doi.org/10.26742/panggung.v29i1.811

[18] F. Adhitya, Preservation of Maras Taun Traditional Ceremony Tradition of National Character Values in the Community of Sukamandi Village, Damar District, East Belitung Regency, Bangka Belitung Province (Descriptive Study in Sukamandi Village), FKIP UNPAS, 2016.

[19] A. Merinda, Communication Activities of Maras Taun Traditional Ceremony in the Nasik Strait of Belitung (Ethnographic Study of Communication Activities of the Maras Taun Traditional Ceremony in the Nasik Strait, Belitung), Bandung, 2014.
[20] A. D. Wildan, Irwandi, Peran Dukun Kampung Dalam Kehidupan Masyarakat Melayu Belitung, Jurnal Kelola: Jurnal Ilmu Sosial 1 (2018) 1-16. DOI: https://doi.org/10.15575/jk.v1i1.3764

[21] B. R. Education, C. O. Team, Bunga Rampai Eating Bedulang Workshop. Belitung Regency: Education and Culture Office of Belitung Regency, 2013.

[22] P. I. A. Anrosana, A. A. Gemaputri, Kajian Daya Dukung (Carrying Capacity) Lingkungan Perairan Pantai Pasir Putih Situbondo bagi Pengembangan Usaha Karamba Jaring Apung, Jurnal Ilmiah Inovasi 17 (2018) 73-79. DOI: https://doi.org/10.25047/jii.v17i2.546

[23] F. Adinugraha, Tari Dolalak Sebagai Bentuk Pendekatan Kearifan Lokal Dan Budaya (Kalbu) Pada Mata Pelajaran Biologi, EDUKA: Jurnal Pendidikan Hukum dan Bisnis 3 (2018). DOI: https://doi.org/10.32493/eduka.v3i1.3803 